\title{
THE FORMALIZATION OF TEMPORARY URBANISM IN TORONTO AND PROPOSED EQUITY-BASED REGULATORY FRAMEWORK
}

\author{
By \\ Abraham Gerald Plunkett-Latimer \\ BA, Carleton University, 2008 \\ MA, Carleton University, 2010 \\ A Major Research Paper \\ Presented to Ryerson University \\ In partial fulfillment of the requirements for the degree of \\ Master of Planning \\ In \\ Urban Development
}

Toronto, Ontario, Canada, 2019

(C) Abraham Plunkett-Latimer 2019 
I hereby declare that I am the sole author of this MRP. This is a true copy of the MRP, including any required final revisions.

I authorize Ryerson University to lend this MRP to other institutions or individuals for the purpose of scholarly research

I further authorize Ryerson University to reproduce this MRP by photocopying or by other means, in total or in part, at the request of other institutions or individuals for the purpose of scholarly research.

I understand that my MRP may be made electronically available to the public. 


\title{
THE FORMALIZATION OF TEMPORARY URBANISM IN TORONTO AND PROPOSED EQUITY-BASED REGULATORY FRAMEWORK
}

\author{
(c) Abraham Plunkett-Latimer, 2019 \\ Master of Planning \\ In \\ Urban Development \\ Ryerson University
}

\begin{abstract}
In the past decade since the introduction of temporary urban discourse promising "faster, lighter, and cheaper" planning and a radical reorganization of power between regulators, land owners, and the public, temporary urbanism has become increasingly integrated in formal planning structures. This paper explores how temporary urbanism is being practiced in Toronto and what impact this formalizing process has had on its ability to achieve its claimed goals of democracy, equity, and diversity.

This paper specifically assesses the impact that the City of Toronto's regulatory framework has had on these goals. It concludes by examining how three other cities have created temporary use frameworks, Amsterdam, London, and Vancouver and highlights what lessons can be transferred to the context of Toronto.
\end{abstract}

Key words: temporary urbanism, policy, equity 


\section{Acknowledgements}

I would like to thank my supervisor, Zhixi Zhuang, for her patient guidance and thoughtful insights in realizing this project. I would also like to thank my second reader, Pamela Robinson for her helpful critiques and flexibility. I am so grateful for both of your kindness and support.

I would also like to thank the Province of Ontario for funding this project through the Ontario Graduate Scholarship program.

Finally, I would like to thank my partner, Corinna, and daughter, Matilda, for their sacrifices over the past two years. Thank you, Corinna, for being my tutor, cheerleader, delivery driver, cook, therapist, and friend. Tilly, you and I started this journey together. You inspired me to take a risk and try something new. I hope you will always have the courage to do the same. I love you both and owe you many visits to see rhinos, stinky and otherwise. 


\section{Table of Contents}

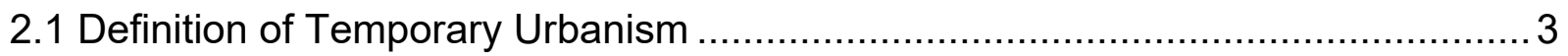

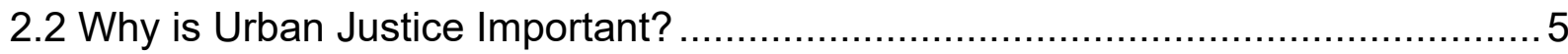

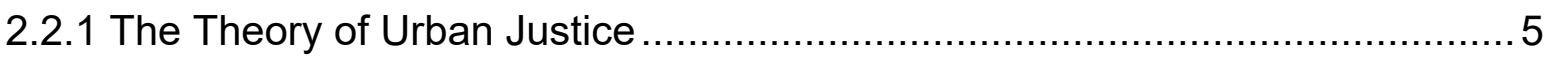

2.2.2 Justice in the City of Toronto's Policies ................................................ 7

2.3 Why is Temporary Urbanism Relevant to the Concept of Urban Justice? ............ 8

3.1 Temporary Urbanism as Tactical Urbanism ................................................... 9

3.2 Temporary Urbanism as a Development Strategy ....................................... 11

3.3 Temporary Urbanism as Exploitation ........................................................... 13

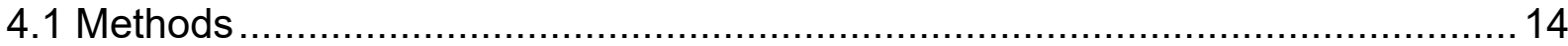

4.2 Contribution of this Study to the Planning Field ......................................... 17

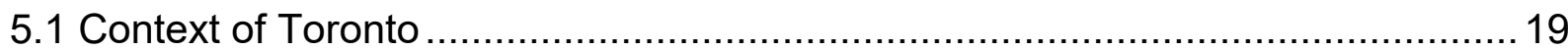

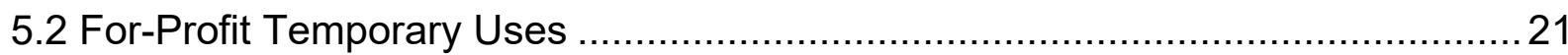

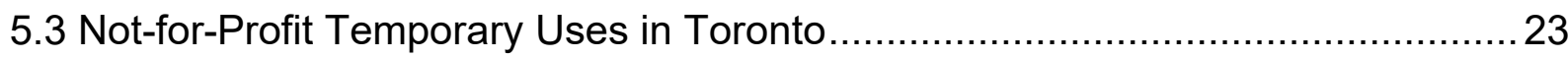

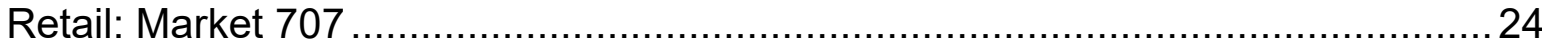

Community Space: Weston-Mount Dennis Boys and Girls Club ..........................27

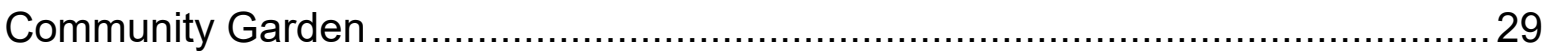

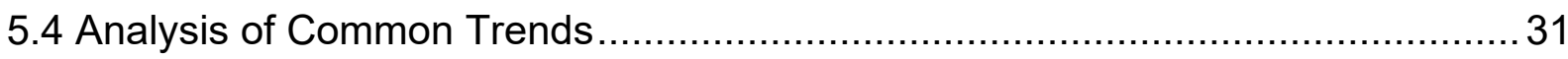

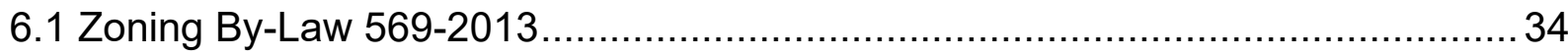

6.2 Disconnection Between Departments and Districts and Overlapping Jurisdictions 35

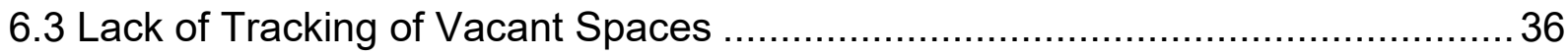

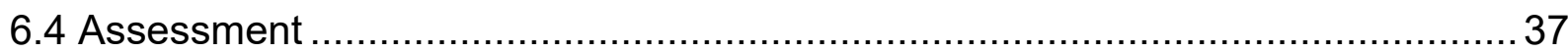

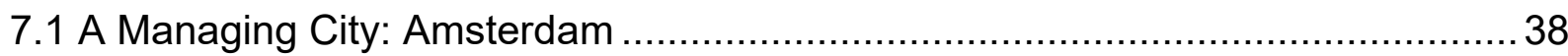

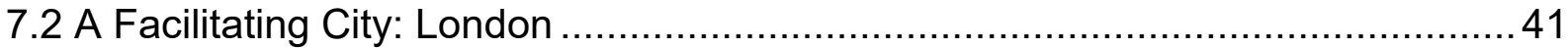

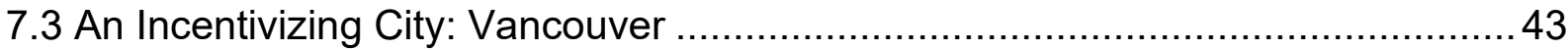

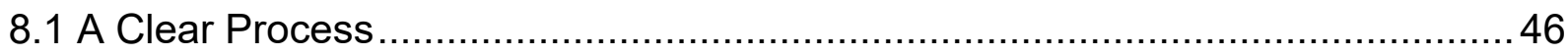

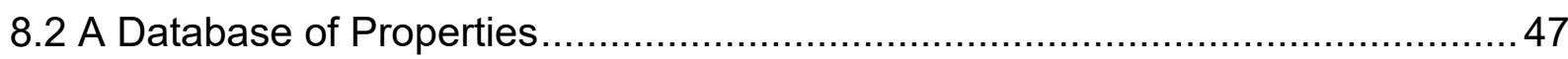

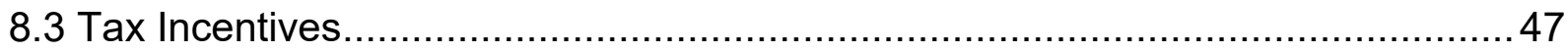

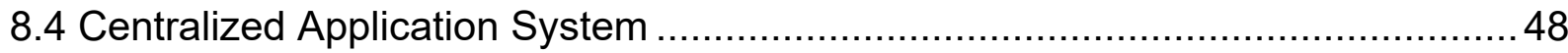

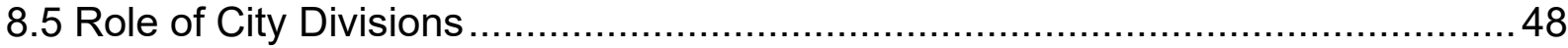




\section{List of Figures}

\section{Figure 1:}

Market 707 with Scadding Court Community Centre in Background, 707 Dundas Street West, Toronto, Ontario. October 24, 2018.

Figure 2:

St. Alban's Boys and Girls Club, 100 Emmett Ave, York, ON. April 18, 2019.

Figure 3:

Oben Flats Community Garden, 307 Sherbourne St., Toronto, Ontario. April 16, 2019. 


\section{SECTION 1: INTRODUCTION}

"Lighter, quicker, cheaper." This phrase, coined by Eric Reynolds in 2010, has served as a rallying cry for the temporary urbanist movement (Maciver, 2010). This movement promised a radical reimagining of the planning framework emphasizing temporary, low cost, DIY interventions in cities by the community for the community. It imagined itself as redistributing power in a hierarchical land use system from developers and bureaucrats to the community itself, allowing almost anyone to become a developer of their own city (Oswalt, Overmeyer, \& Misselwitz, 2013; Brenner, 2015). Central to this goal was the creation of a more just city.

Temporary urbanism was framed as upsetting the status quo by giving members of the community the ability to take advantage of vacant spaces, so-called "holes in the urban fabric," and give them new purposes such as community gardens, pop-up cafés, and art installations (McGrath, 2017). It began with informal uses of land, skirting legal regulations and often without the sanction of property owners.

Ten years on from the beginning of the temporary urbanism movement, its presence is increasingly visible in cities across Europe and North America. Indeed, a 100,000 square foot shipping container market is scheduled to open in Toronto in the Spring of 2019 (McKeen, 2017). Yet, despite the increasing visibility of temporary urbanism, the status quo has not been upset. Planning departments and municipal councils have not been swept away into obsolescence in the face of "lighter, quicker, cheaper" land uses. Rather, recent academic literature has observed that the temporary urbanist movement, began as an attempt to undermine development-oriented planning processes and create "spaces outside" of traditional city planning and project 
development has largely been co-opted by them (Vooren, Vleugel, \& Zwietering, 2003). Increasingly informal temporary urbanism has been integrated into formal planning processes and the property market. It is now used by municipalities, developers, and landlords alike as a strategy for development (Andres, 2013; Patti \& Polyak, 2015).

Yet despite this shift of temporary urbanism from the margins to the centre, discourse surrounding the practice has yet to catch up. It continues to be framed as a "bottom-up" movement allowing for cultural vibrancy, radical citizen involvement in development, and the dynamic shaping of urban space undermining the hierarchical land use planning system. In short, it claims to improve urban justice. There is a significant gap in the literature regarding the impact that formalizing temporary use practice might have on its viability for achieving these social goals.

The purpose of this major research paper is to explore the current state of our knowledge regarding the impact of municipal regulation on temporary urbanism. Specifically, it seeks to understand how temporary initiatives might be contributing to improving urban justice and how the regulatory framework helps or hinders this goal. In order to understand this impact and propose improvement there are three key questions I wish to explore:

1. How is temporary urbanism used in Toronto and what is the role of municipal government in creating temporary spaces? What Toronto's regulatory framework and what impact does it have on temporary use projects?

2. How have other cities regulated temporary uses?

3. How can Toronto's Regulatory Framework for Temporary Use be More Just?

These guiding questions are designed to help illuminate differences between discourses and practice regarding temporary urbanism in Toronto, highlight the unique character of 
Toronto's practice of temporary urbanism, and help to create a better "formalized" temporary urbanism that better achieves the social benefits associated with the movement. In order to explore this concept of "social benefits" this study draws upon the concept of urban justice formulated by Susan Fainstein as its theoretical underpinning.

\section{Section 2: Definitions}

\subsection{Definition of Temporary Urbanism}

Before entering into an analysis of the literature and case studies, it is worth exploring the definition of temporary urbanism that will be used in this research paper. "Temporary Urbanism" is a term that is difficult to define. It is alternately known as "popup urbanism," "tactical urbanism, "guerilla urbanism," "temporary use," and "interim use" and has been used as a catch-all term to include a number of city building practices. It encompasses a range of activities from art exhibits, to pop-up shops, to urban gardens, to short term leases, to marketing displays, or even Toronto's recent King Street Pilot (Lee-Shanok, 2018). Peter Bishop and Lesley Williams observe that the "temporariness" of a use may, in fact, not be apparent until after it has disappeared and thus proved itself to be "temporary" (Bishop and Williams, 2012). One solution they propose is to define temporary use by the intention behind it. They note that "the definition is not based on the nature of the use, or whether rent is paid, or whether a use if formal or informal, or even on the scale, endurance or longevity of a temporary use, but rather the intention of the user, developer or planner that the use should be temporary" (Bishop and Williams, 2012, 3). They emphasize that in order for a use to be considered "temporary" the time-limited nature of the use should be explicit (Bishop and Williams, 2012, 5). 
Alternatively, Németh and Langhorst (2014) consider temporary urbanism to be defined not as a concept in and of itself, but rather in opposition to permanence. They note that a use should be considered "temporary" if a property is slated for a more permanent use in the future. So, for example, this could describe Brownfield Lands on which future development is to take place. An example of this type of development in Toronto is the temporary market located at 335 Yonge Street. This lot, left vacant after a fire has been used as the site for food trucks and shipping container restaurants since 2015. The owners intend to develop the land at some future date, but have allowed a number of small restaurants to use the site in the interim. In this case the "distinctions assume that temporary use is secondary or provisional, a stand-in or substitute for the preferred permanent option'” (Németh and Langhorst 2014, 144).

A third body of scholarship positions temporary urbanism as a strategy of the tactical urbanist movement. Key characteristics in this definition include its low-cost, low-risk, do-it-yourself nature (US Department of Housing, 2014). This scholarship highlights that temporary urban projects are able to be constructed by individuals or small groups themselves due to their low cost. A shipping container, for example, costs as little as $\$ 17,000$ (Diversity Institute, 2013). This low-cost quality is imagined to mitigate the risk that would otherwise be associated with more permanent kinds of investment. It is worth noting that temporary urbanism intersects closely with the tactical urbanist movement but is distinct. Tactical urbanism has been defined as "a city, organizational, and/or citizen-led approach to neighborhood building using short-term, low-cost, and scalable interventions to catalyze long-term change (Tactical Urbanists Guide, 2019)." Temporariness is, therefore, a key component of tactical urbanism, but 
does not encompass the movement in its entirety. Temporary urbanism, likewise, often incorporates tactical urbanist discourses such as low cost and do-it-yourself (DIY) methods. This does not, however, encompass the entirety of the temporary urbanist movement, as temporary urbanist projects may be large in scale and involve higher budgets, such as a recently-opened, $10,500 \mathrm{~m}^{2}$ market constructed from 120 shipping containers at 28 Bathurst Street (Ricci, 2019). As such, although these concepts are intertwined in much of the literature, they should be considered distinct from one another.

For the purpose of this study I define temporary urbanism using components of these two definitions. A use should be considered "temporary" if it is intended to be temporary and if its use differs from a permanent use projected for the future. Given the wide range of uses that temporary urbanism can take, such as community gardens, pop-up shops, or even shipping container housing, I consider further refinement of the definition too limiting to be useful.

\subsection{Why is Urban Justice Important?}

\subsubsection{The Theory of Urban Justice}

A second point of distinction is to highlight my definition of "justice" and justify my assumption that justice is a valuable outcome for a proposed temporary use regulatory framework. My use of the term "justice" is derived primarily from Susan Fainstein's concept of "the just city." Fainstein's theory of justice draws upon earlier planning theory stretching back to the 1970 s which identified that spatial relations are inherently connected to power imbalances. She observes that in cities the "crucial issue for study is how power relations (as determined by the interaction between state authority, 
economic ownership, and urban residents) affect urban outcomes and, in particular, how spatial relations reinforce injustice (Fainstein, 2014, 2). By this she refers to systemic disadvantages experienced by some members of the population due to, for example, zoning being used to limit density in order to preserve property values.

Building upon this assumption of inequality inherent in urban spatial relations, Fainstein proposes a model for urban justice, emphasizing that planners should act to ameliorate rather than support urban inequality. Her model of justice includes three key qualities: democracy, diversity, and equity. Fainstein notes that in a broad analysis of contemporary planning theory and public policy these three values tend to be implicit in the broader goal of reducing power differentials in cities. By democracy Fainstein refers to the goal of giving decision-making opportunities to a broader range of the population, particularly including groups that have historically been underrepresented such as those with low incomes or those from minority communities. By diversity, Fainstein refers to heterogeneity in cities. She argues that cities must be spaces where individuals who differ according to their identity regarding classifications such as sex, class, ethnicity and sexual orientation have equal right to public space. With equity, Fainstein argues that we reach the core of special injustice. She attempts to highlight how policies may benefit relatively disadvantaged social groups based on income or marginality, noting for instance that policies such as "stressing housing development for low income households, preventing involuntary displacement, giving priority in economic development to the interests of employees and small businesses, and lowering intraurban transit fares (Fainstein, 2014, 12). At its core, these three elements of the "just 
city" are designed to emphasis more equality in terms of outcomes for individuals otherwise excluded from power in the urban context.

\subsubsection{Justice in the City of Toronto's Policies}

This concept of urban justice as a lens through which to analyze the outcomes of initiatives and policies translates well to the policy context of Toronto. High level policies emphasize similar goals for creating the "just city." The City of Toronto Official Plan frames its overall policy as one of "sustainability." This concept includes much of the same criteria that Fainstein observed in planning literature. The plan notes that sustainability includes such qualities as "social equity and inclusion, environmental protection, good governance and city building" (City of Toronto, 2015, s1.2). Elements of justice are central to the Official Plan. The value of equity is referenced fifteen times, cultural diversity eighteen times, and democracy and participation fifty-five times (City of Toronto, 2015).

The City of Toronto Strong Neighbourhood's Strategy likewise places justice at the core of its mission. The plan frames itself as fundamentally a strategy for equity stating that its goal is to "remove the differences between our neighbourhoods that are unjust, unnecessary, and unfair." Within this model there are three overarching goals: activating people, involving providing essential services, building community capacity, and encouraging resident leadership and ownership in the planning, implementation, and evaluation of initiatives [...] opening up new ways for people to access the [planning] process (City of Toronto, 2017, 8). The second overarching goal is "activating resources" including "services, programs, public space, and amenities that are relevant and accessible to residents." Third it emphasizes activating neighbourhood- 
friendly policies with the goal of increasing unfair negative impacts on neighbourhoods by changing the way municipal services are planned and delivered (City of Toronto, 2017). Fainstein's concept of justice as a shorthand way to refer to policies emphasizing democracy, diversity, and equity in the urban development process have, therefore, a significant presence in the City of Toronto's high-level policies. The City has recognized that there is significantly inequality in the spatial distribution of power and opportunity and sees its role as a mediating force in this inequality.

\subsection{Why is Temporary Urbanism Relevant to the Concept of Urban Justice?}

Temporary use has been shown to have significant potential for addressing inequality in the relationship between state authority, economic ownership, and urban residents. In the context of informal temporary land use, individuals and community groups have created urban projects largely outside of the existing land use framework exerting direct influence on vacant land without mediating pressures of planning approval and without ownership. Community gardens, for example, have been created in which communities temporary turn private space into public space often without knowledge or consent of the owner. Its value for giving greater access to the public in the planning process has been well established (Bishop \& Williams, 2012).

\section{SECTION 3: LITERATURE REVIEW}

Research on temporary urbanism has proliferated in the years since it was introduced as a key planning concept in the late 2000s. Despite some overlap, broadly this scholarship can be divided into three categories, early descriptions deriving from the tactical urbanist movement, recognition that temporary urbanist practices might be 
employed by planners, and finally criticisms of the movement relating to gentrification, precarity, and exploitation of temporary users. The overall narrative that the literature reveals is that of the gradual integration of temporary use practices into formal land uses and the impacts caused by this trend.

\subsection{Temporary Urbanism as Tactical Urbanism}

The earliest literature exploring the planning implications of temporary urbanism has its roots in in the tactical urbanist movement. Tactical or DIY urbanism is defined as individuals making unsanctioned changes to urban spaces. Some recent examples of this movement in Toronto include the building of a staircase at Tom Riley Park in Etobicoke in 2017 (McLaughlin, 2017). Although citizens have always made unsanctioned changes to their cities, beginning in the late 2000s, citizens began increasingly to self-consciously identify their actions as part of the "Tactical Urbanist" or "DIY Urbanist" movement (Finn, 2014). Some scholars have pinpointed the rise in citizen activist as a response to austerity movements adopted by municipal governments as a response to the 2008 recession (Ferreri, 2015; Lydon and Garcia, 2015). As part of this movement, creative citizens taking over vacant lots as community gardens or temporary retail spaces for their handmade goods imagined themselves as redefining power imbalances and challenging the existing planning framework by reclaiming disused private spaces for public use (Lydon and Garcia, 2015).

Lauren Andres (2013) makes explicit how temporary uses may be used to disrupt power imbalances inherent in the system of planning. She observes that temporary use projects involve three key stakeholders: planners, property owners, and the temporary users. In traditional land use power is heavily skewed toward landowners and land 
regulators. It has been observed, for example, that planning regulations, such as zoning, often serve the intentional purpose of maintaining property values (Yiftachel, 1998). Andres argues that temporary uses create "differential spaces which are not ordered by planning strategy" (Andres, 2013: 6). She suggests that these "differential spaces" have the potential to question the spatial dimension of everyday power relationships specifically between landowners, local authorities and temporary and can help to make visible the tension between users who appropriated space and other actors, supposedly controlling the same space. She observes these tensions coming to the forefront in the context of the transformation trajectory of derelict spaces from a period of weak planning to a stage of master planning (Andres, 2013: 6). This emphasis on the democratizing power of temporary use is reiterated by Andres (2013) who noted that "Whereas top-down master planning relies on the idea of permanence, stability, linearity and control and often has no means of developing non-commercially exploitable areas, more unplanned temporary uses can enable flexible, innovative and bottom-top approaches which are not exclusively related to monetary values (Andres, 2013: 763)."

At the core of these early explorations into how temporary urbanism was being used by community groups is the idea that it serves to undermine traditional power relations in the planning process, rebalancing authority away from regulators and landowners and putting it into the hands of individual members of the community. Early identification of temporary urbanism with equity continues to be a central theme in discourses surrounding the practice, particularly in media representations. One 
proponent explicitly makes reference to the practice's role in achieving Fainstein's "just

city." Monte Königs noted: He writes:

"As a solution, temporary use can reactivate prominent spaces in the urban landscape, it can break former boundaries between neighbourhoods and it can be the first step for unusual ideas to become professional but it can also be a political statement. A plea first made by Henry Lefebvre and revitalised by Susan Fainstein very much fits the principles of temporary use. This plea stands for a new urbanism where the urban landscape is used to fulfil benefits of all who live in the city. The executives of temporary use projects often call themselves urban pioneers to give their project exactly this political charge. Urban pioneers try to create free spaces accessible and beneficial for all. This contrasts the dominant urban landscape that is shaped by a focus on economic growth. This focus leads to an unequal distribution of opportunities in the city with all types of privileged spaces based on economic differences. The events and practices in temporary use projects are not merely based on profit or economic growth but more so on creativity and cultural significance of the urban space. Mostly urban pioneers try to create areas where citizens can reconnect with each other in activities, on markets and on festivals or where citizens can garden without being dependant on commercial interest or economic capital (Königs, 2012).

What is key here is that he views temporary use as fundamentally fulfilling the objectives of the "just city" in creating equal opportunities for all. This is self-consciously contrasted with the dominant urban landscape which he perceives as focused on economic growth.

\subsection{Temporary Urbanism as a Development Strategy}

Despite its activist beginnings, however, as early as 2013 planners began to recognize the significant potential offered by harnessing the creative power of DIY urbanism. In both Canada and abroad, planners began to publish toolkits for how to integrate temporary urbanism into formal planning structures (Pfeifer, 2013; Graham, 2012; Sweeting, 2015). These toolkits emphasize that temporary urbanism presents a number of advantages over traditional "permanent" urbanism including the ability of 
cities to test out projects before committing to infrastructure changes, making space for arts and culture, and acting as a development tool to revitalize areas that are underperforming economically. These toolkits frame temporary urbanism as a win-win situation in which community engagement, and access to affordable space for marginalized communities are perfectly matched with economic revitalization. A key supporter of this temporary urbanism as development strategy are Peter Bishop and Leslie Williams (2012).

Central to this concept of temporary use as a tool for regeneration was its relationship to cities struggling with declines in their industrial base and the fallout of the 2008 subprime mortgage crisis. At this time development slowed significantly across many cities in the United States and Europe. Many cities struggled with vacant industrial properties and perceived temporary urbanism as a means by which declining cities could be revitalized (Lehtovuori \& Ruoppila, 2017; Nemeth and Langhorst, 2014).

Since the mid 2010s cities have increasingly begun using temporary urbanism as a development strategy. A recent example of this form of "crowd sourced planning" is the City of Toronto's ShapeLab project, which seeks to create sanctioned pop-up displays along King Street (Sloan, 2018). The movement, which was originally meant to undermine the formal planning process, thus became largely co-opted by it.

It is key to observe that these "how-to" guides largely do not anticipate negative outcomes from formalizing previously informal practices. Rather, many of these studies rest on the assumption that equity and profit can be achieved in equal measures. The assumption is that the just outcomes associated with tactical urbanism will be transferred to an institutionalized context. 


\subsection{Temporary Urbanism as Exploitation}

This co-opting of temporary urbanism is at the heart of a more recent body of scholarship which has sought to uncover some of the tensions associated with moving temporary urbanism from the periphery to the mainstream. Mara Ferreri and Andreas Lang have observed that despite discourses regarding the egalitarian benefits of temporary urbanism, what Ferreri calls the "seductions of temporary urbanism," these discourses can serve to obscure exploitation and displacement in temporary use projects (Ferreri, 2015).

In Ferreri and Lang's study of London's experience with temporary use projects following the 2012 Olympic Games, they sought to explore the broader social and economic impacts of temporary use projects. they noted that temporary use projects typically take advantage of freelance, mobile workers who are able to make use of vacant space with little notice, leveraging existing networks of social capital. They highlight that within this model the "freelancer takes upon him/herself the financial and physical risks connected with the activities of the space" (Ferreri and Lang, 2015, 136). Further compounding this difficulty, Ferreri and Lang observed that the short term and fluid nature of temporary uses tends to be at odds with the regulatory environment which is very strict in terms of ticketing, insurance, and licensing (Ferreri and Lang, 2015). In this way, temporary uses, which are framed in the tactical urbanist literature as having broken down the traditional power dynamic between owner, user, largely affirm it. Not only this, but they make the unequal balance of power in this model even more unbalanced by placing the burden of activating spaces quickly while meeting existing regulatory checks, and intentionally or unintentionally raising the value of the land on 
which the temporary use may take place through its activation. This theme of the potential for gentrification and displacement as a result of temporary use initiatives has been explored in several other studies (Andres, 2015; Madanipour, 2018). In this model temporary users of a site might function to dispossess themselves through urban regeneration caused by their activities.

It is imperative to recognize that these three discourses regarding temporary use exist, as more recent studies greatly complicate the model presented by the earlier tactical urbanist and urban development schools of thought. Tactical urbanist discourses can, moreover, serve to obscure economic processes underlying them. Urban policy makers must recognize that their own action (or inaction) are inherently bound to the land use system, which itself is intimately bound to questions of power. As such, policies must consider how vulnerable groups might be impacted. In the following section I examine how temporary urbanism is used and regulated in Toronto considering the impact of these discourses established in secondary literature.

\section{Section 4: Research Methods}

\subsection{Methods}

This study relies upon a secondary research approach drawing together a review of existing literature on temporary urbanism, examination of local case studies to establish the form of temporary urbanism in Toronto and international best practices, and finally it employs policy analysis to determine how existing policies may be positively, neutrally, or negatively affecting the implementation of temporary urban projects in Toronto. This method was employed in order to merge bodies of literature operating in isolation, separated by geographic focus or by intended audience 
(academic or lay) and examine how these findings may shed light on the context of Toronto's planning regulations and culture. In particular, this method is designed to filter the City of Toronto's current policies through the lens of power imbalances in the planning process identified in the literature review above.

This study uses secondary academic and media sources, planning reports, and policy documents to highlight three key sections of analysis. The first section, highlighting case studies of how temporary urbanism is practiced in Toronto, employs planning and policy reports and media interviews with site organizers. The second section, analyzing barriers in Toronto's current system, analyzes Toronto's policy framework, including official plan policies and zoning by-laws and also integrates planning reports. The final section on national and international cases studies employs planning reports, policy documents, and media descriptions. Although this research is based primarily on policy analysis and secondary research, analyzing these sources collectively reveals new practical and theoretical considerations for the Toronto context.

Policy analysis was conducted as a "barrier review." The goal of this process was to identify where Toronto's current policies on temporary urbanism might be leaving some individuals and groups at a systemic disadvantage. Precedents for this kind of review of policy are common throughout the literature on equity in Canada. Two key models that this study relied upon are The Ontario Human Rights Commission's guide to preventing, removing, and reviewing barriers and the City for All Women Initiative's (CAWI) guide for advancing equity and inclusion for municipalities (Ontario Human Rights Commission, 2019; CAWI, 2015). Both of these organizations stress the importance of systematically reviewing barriers toward equity and inclusion. CAWI 
identifies that policy, practices, and procedures can form a key barrier toward creating an inclusive city and so these barriers must be systematically identified and addressed (CAWI, 2015). As such, this study adopts this "barrier review" framework for analyzing the City of Toronto's policies. What are the policies, practices, and procedures that may create barriers for communities identified as vulnerable, including recent immigrants, persons living in poverty, persons with disabilities, and the LGBTQ community (CAWI, 2015).

Local Toronto case studies were selected according to three key criteria: first, they were chosen because of the availability of information. Both Market 707 and the St. Alban's Boy's and Girls Club have received some previously scholarly analysis. Secondly, they were chosen to represent different types of temporary uses that are being explored in Toronto: retail, community centre, and community garden. Finally, they were chosen because all are small-scale, community-driven, demonstrate a clear mandate for social improvement and so highlight the potential for temporary uses to offer community benefits, despite facing policy barriers.

National and International case studies were also chosen according to several key criteria. First, they have all been studied in secondary literature and so information was available; second they were all referenced in the literature as examples of best practices regarding temporary urbanism; and third, they all were facing similar issues with rapid intensification and lack of affordable space that is being faced in Toronto. This criteria set these cities apart from many others in the literature who were using temporary urbanism as a redevelopment strategy rather than as a means by which to unlock affordable space. These cities were likewise chosen because they represent 
illuminating examples of different strategies for formalizing temporary urbanism into their planning frameworks: what I have termed "managing cities," "facilitating cities," and "incentivizing cities." Managing cities are those who actively incorporate temporary uses into their policy frameworks, designating lands for temporary uses, for example.

Facilitating cities do not actively manage temporary uses, but help to facilitate by simplifying processes and connecting users with vacant land. Incentivizing cities are not actively involved in managing or facilitating temporary uses, but encourage private landowners to lease space for community purposes through tax incentives. These three categories are not mutually exclusive, but do represent a scale of municipal involvement in the regulation of temporary uses from heavy to light and encompass the strategies identified in the secondary literature.

\subsection{Contribution of this Study to the Planning Field}

This study fills an important gap in research on temporary urbanism by making municipal policy its core focus. In the existing literature, both concerning Toronto and internationally, much of the research on temporary urbanism has been focused on users rather than regulators (Bishop \& Williams, 2012). They present municipal regulations as obstacles to be overcome rather than as contributors to temporary urbanist projects (Oswalt, Overmeyer, Misselwitz, 2013). This study makes three key contributions that would be helpful for policy-makers: first, it draws attention to the disconnect between academic literature and the media in terms of the purported benefits and drawbacks of temporary urbanism; second, it highlights the negative impact existing policies regarding temporary urbanism may be having on creating equity in Toronto; finally, it highlights the experience of other jurisdictions to ward against potential pitfalls in creating a temporary 
use policy. This study is necessary because practitioners of temporary urbanism have repeatedly identified city policies as a significant obstacle to their projects. There have been multiple calls for the City of Toronto to revise its policies regarding temporary development across a range of organizations from Member of Parliament, Adam Vaughan, to Kevin Lee, director of Scadding Court Community Centre, to Claire Nelischer from the Ryerson City Building Institute, to Christopher Hume from the Toronto Star (Ferguson, 2017; Nelischer, 2014; Hume, 2014). In the broader context, many cities are currently reviewing how temporary use projects are being implemented in their jurisdictions and how they may be facilitated. Such studies have recently been published in London, United Kingdom and are underway in Montréal, Canada (Bosetti, 2018; Conseil Jeunesse de Montreal, 2019).

\section{Section 5: Temporary URbanism Practice in ToRonto}

This section argues that temporary urban land uses in Toronto are highly integrated in the formal planning framework. I suggest that organizations have a significant impact on increasing "justice" in the context of Toronto that aligns with the City's broad goals for social justice. Despite these positive effects, however, I observe that municipal policy is a significant barrier toward the implementation of temporary land uses. In order to explore this theme, I examine case studies representing different types of temporary land use and how municipal policy has affected their implementation. I then consider what elements of Toronto's regulatory framework might function as barriers toward temporary urban projects. 


\subsection{Context of Toronto}

I observed above that temporary urbanism is highly diverse in its application and that its form and function have varied significantly across time and space. As such, it is necessary to examine what function this practice is currently serving in Toronto. In much of the literature, temporary urbanism is associated with "decaying" cities. Planning literature highlights that temporary urbanism has taken hold primarily in areas facing significant economic decline. Much of the literature focuses on post-soviet Berlin in the 1990s and early 2000s and on cities in the United States and Western Europe following the recession caused by the subprime mortgage crisis. It notes that many temporary urbanism projects took hold as a result of the 2008 subprime mortgage crisis and that temporary urbanism became a way to utilize properties left vacant through lack of investment or a change in function (Colomb, 2012; Németh and Langhorst, 2014 ). A key example of the function of temporary urbanism in the context of decline is Detroit's urban farming movement in which vacant properties were repurposed as garden plots to fill a gap in amenities and improve food security (White, 2011).

The context of Toronto is very different from many of these other cities "in decline." Toronto is a major city within North America that is currently experiencing unprecedented development and a corresponding lack of affordable space. Rider Levitt Bucknall's crane index survey, standing as a marker of development trends, notes that in late 2018 Toronto had nearly 100 cranes in the sky, 32 more than in any other North American city (Rider Levett Bucknall, 2018).

The Toronto Real Estate Board reports also highlight a growing problem of affordability in the city. The Toronto Real Estate Board's most recent commercial realty 
report reveals that the average cost per square foot for Commercial/Retail space has increased by $40 \%$ percent since the third quarter of 2017 and now tops $\$ 25 /$ sq foot TREB, 2018). Vacancy rates for commercial and office space likewise have now fallen to historic lows, reaching 2.5\% vacancy at the end of 2018 (Powell, 2018).

Within this context, achieving equitable access to space in the city for disadvantaged individuals and communities is very difficult. Indeed, planners have acknowledged that finding appropriate space for infrastructure such as parks, daycares, community centres, and schools is a major challenge due to the lack of available land (Chief Planner, 2007).

The purpose of this section is to highlight what form temporary use projects typically take in Toronto and what is their purpose. It concludes by considering their role in the creation of a "just city." I propose that temporary urbanism has emerged in Toronto largely for two purposes: as a marketing strategy and as a strategy for addressing this lack of affordable space. These two categories of projects differ greatly from one another in function and character, but are typically referred to by the same terminology. As such it is necessary to distinguish between the two.

In Toronto Neighbourhood revitalization appears to function only as an unintended secondary benefit unlike other cities, such as Detroit where vacant properties are perceived as a major issue (Ikonomova, 2019). At present there is no tracking mechanism through which to identify temporary use projects in Toronto and so an exhaustive analysis of all temporary uses is not possible. As such, I have attempted to identify representative project types based upon those highlighted in the literature review, which I will explore as case studies. A key question posed to each of these case 
studies is whether they are achieving the goal of improving "justice" in Toronto by improving democracy, diversity, and equity in line with the proposed benefits of temporary space in the literature. In light of these results, I examine how the City of Toronto's regulatory framework impacts the achievement of these goals.

\subsection{For-Profit Temporary Uses}

It is important to distinguish that many practices are contained in the discourse of temporary or "pop-up" urbanism in Toronto. A body of literature has noted that the discourse, which originally came from the field of tactical urbanism, is now employed as a marketing or development strategy. The same methods and language are used by each of these temporary forms of urbanism but with very different intents. If Toronto is to develop a regulatory structure based upon the argument that temporary uses are providing useful community service and so should be encouraged, it is imperative that a distinction between these types of temporary uses, their function, and their aims is recognized. Otherwise, neo-liberal arguments for deregulation might be conflated with those encouraging provision of community benefits.

A useful way to distinguish between these types of "pop-up" uses is to focus their intentions. Specifically, I distinguish between their primary and secondary goals. The first category, which I call "for-profit," places profit as a primary goal of the temporary use with equity benefits, such as increasing community vibrancy, as a secondary goal. In the "not-for-profit" types of temporary use, social equity is placed as a primary goal with profit as a secondary by-product. This schema allows for very different temporary land use types to be distinguished while also recognizing overlaps in outcomes, i.e. profit and social benefits are not mutually exclusive. Nevertheless, the distinction 
between these two types is great enough that it should impact policy decisions and so will be explored here.

This first type of "market-based" temporary use employs many of the tactics established in tactical urbanism relating to the "faster, cheaper, lighter" model. It also employs many of the same discourses, such as "pop-up." This kind of project can take the form of temporary installations of infrastructure on public or private land, such as a shipping container, or can take the form of a short-term leases of existing space. This form of temporary use tends up be centred upon commercial uses.

Proponents of pop-up businesses in the marketing literature identify that it offers business owners two key advantages: the ability to test markets with lower risk temporary shops and the ability to generate marketing buzz.

The risk-mitigating quality of pop-up shops is discussed in much of the secondary literature. Deveau (2018), for example, describes an ice cream shop in Toronto's Junction neighbourhood that is rented out through the winter season to a rotating selection of businesses. These businesses are able to test out concepts in the short term for reduced rent while the space's permanent use would otherwise be unprofitable. Often after this temporary period, businesses scale up to more permanent spaces. This strategy is also employed by existing businesses who wish to test out expansion to new neighbourhoods (Deveau, 2018).

Pop-ups are also used as a marketing strategy (Patterson, 2017). Major landlords in Toronto, such as Oxford Properties, are now designating portions of their properties specifically for pop-ups. Yorkale Mall, for example, now has a space 
permanently dedicated to pop-ups called CONCEPT. They call this an "in-mall multivendor rotating temporary retailer initiative" (Patterson, 2017). The space has been designed with "maximum flexibility" with the goal of bridging the "gap between click and brick" (Patterson, 2017). Square One Mall in Mississauga likewise has hosted themed pop-ups centred around bridal needs, breast cancer awareness, and the Chinese New Year (Patterson, 2017). In many cases these pop-ups are not benefiting from the lowcost or experimental uses. Rather, they employ temporariness to give a sense of urgency or novelty to their marketing. Similar approaches to this have been employed in Dundas Square, which features rotating installations of pop-up shops, often associated with major brands such as Google, who in 2018 installed a temporary doughnut shop to market its products (Carlberg, 2018).

These pop-up shops have been shown to be highly successful as a marketing or risk reduction strategy and secondary literature suggests that they are becoming increasingly identified as an important tool in Toronto's retail landscape (Patterson, 2017). This type of pop-up use, while useful for economic development, does not explicitly contribute to improving justice in Toronto and so when examined through a justice lens, does not require active policy support.

\subsection{Not-for-Profit Temporary Uses in Toronto}

Unlike market-driven temporary use, not-for-profit temporary land uses seek to fill gaps in equitable access to the city by temporarily repurposing land for those who would otherwise be unable to access affordable space. It is significant to note that despite fulfilling very different land use purposes, community organizations have recognized that common goals and tactics underscore their temporary use of land. There has been 
explicit cross-pollination of ideas and methods between organizations creating retail, community, green spaces, and art spaces. As such, it is worth exploring how they share experiences in Toronto's regulatory environment. Here, I explore briefly representative examples of these types of temporary uses in Toronto, their organizers, goals, and outcomes, and the impact of municipal actors on the project. These case studies were chosen because they represent different types of land use, are all relatively established, allowing for assessment of outcomes, and all make explicit their goal of improving equity in the City of Toronto.

\section{Retail: Market 707}

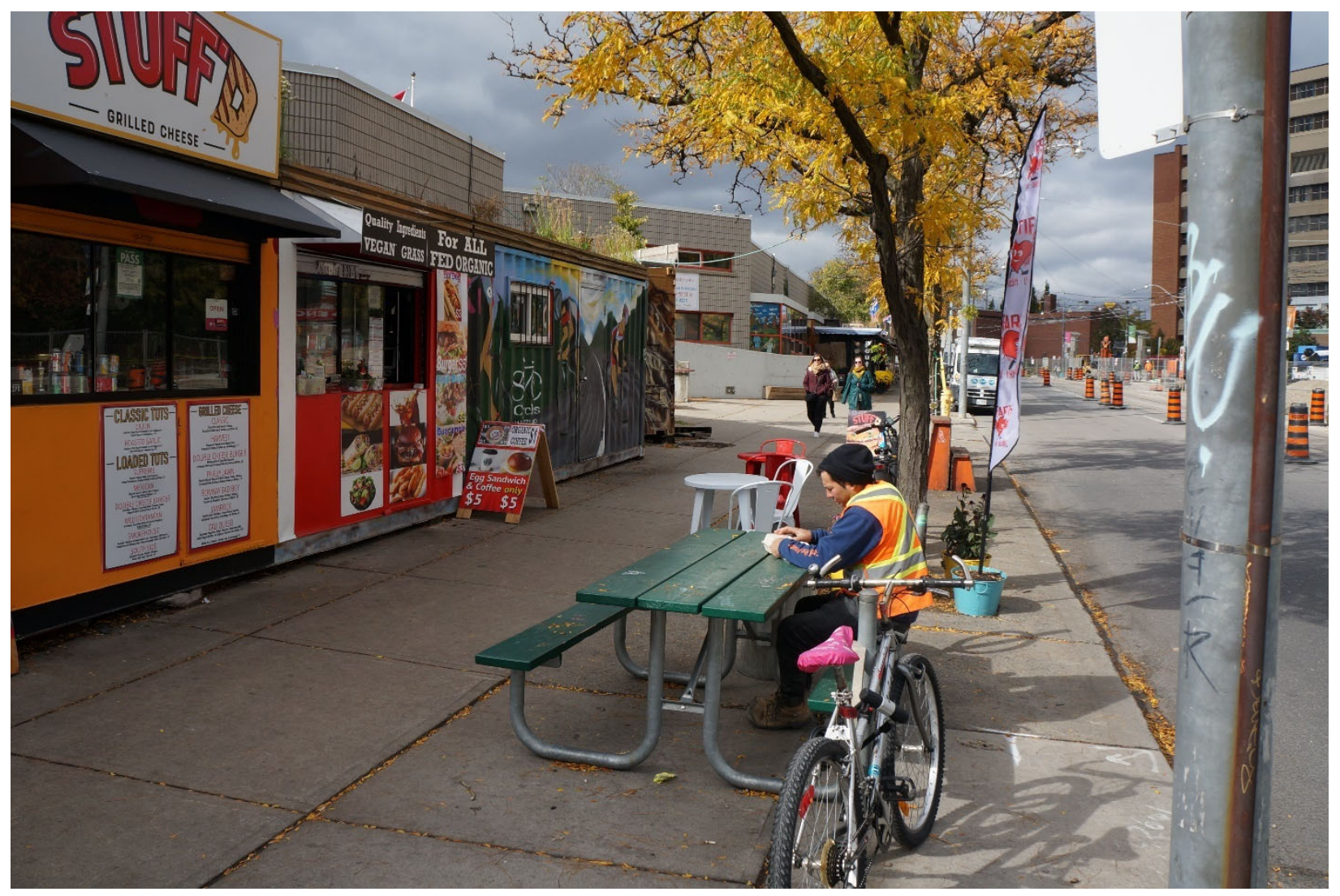

Figure 1: Market 707 with Scadding Court Community Centre in Background. October 24, 2018. 


\section{Description}

The longest standing example of temporary retail land use in Toronto is Scadding Court Community Centre's Market 707 . It was created in 2010 by Kevin Lee, director of the Scadding Court Community Centre, located at 707 Dundas Street West. Inspired by informal shipping container markets that he had observed in Ghana, Lee initially installed two converted shipping containers on the community centre's land fronting Dundas Street which the centre rented out at low cost to entrepreneurs who would otherwise be unable to find affordable space in the city (Leblanc, 2018). The market currently includes 11 shipping containers housing 23 businesses who are charged between $\$ 11$ and $\$ 24$ per day (Ferguson, 2017), a fraction of market rate which, for an $8 \times 20$ ' commercial space could be as much as $\$ 4,000 /$ month in Toronto (TREB, 2018). The market is designed in such a way that the temporary units are easily removeable, but have been located on the site now for nearly a decade.

\section{Outcomes}

Scadding Court identifies its project as a "Social Business Incubation Model." The goal of the project was to activate underutilized space to serve as a business incubator providing low-income aspiring entrepreneurs with "quick and affordable vending spaces", allowing them to "flourish", thereby combining social and economic development goals (Scadding Court, 2019).

Market 707 has been very successful in creating affordable space for lowincome entrepreneurs. Contributes to democracy, equity, diversity by giving retail space 
to those who would otherwise be unable to access it and has a significant wait list for unit vacancies (Skinner, 2012).

Impact of Municipality

Scadding Court has a complex relationship with the municipal regulatory framework. The market was organized through a City of Toronto community centre and is located on municipal land, yet, despite functioning as an arms length organization of the City, the market actually began as an informal project without municipal approval. The project was achieved due to the intervention of then City Councillor Adam Vaughan, who noted that the bureaucratic process was a significant impediment towards the project's realization. He encouraged the community centre to adopt an "ask forgiveness, not permission" approach and begin operations before approvals were obtained and informed City staff that they were "to make it happen" (Ferguson, 2017). Due to the Councillor's personal interest in the project, therefore, normal bureaucratic processes were undermined, allowing for much faster implementation on site than would have been the case if the market were proposed through regular channels. As such, existing policies were perceived as a barrier discouraging the project both by the Councillor and the organizers. 


\section{Community Space: Weston-Mount Dennis Boys and Girls Club}

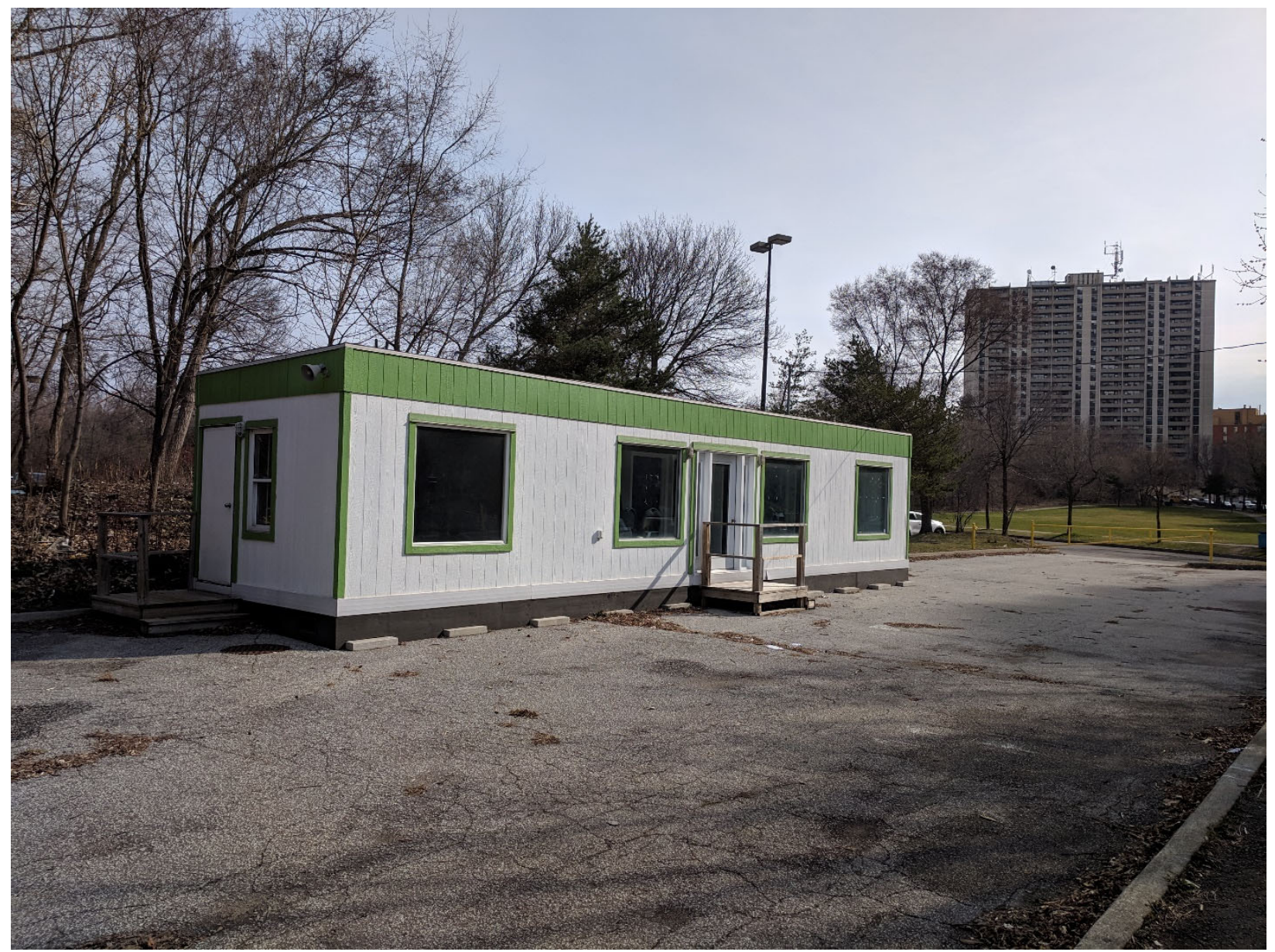

Figure 2: St. Albans Boys and Girls Club Community Centre. April 18, 2019.

\section{Description}

The Weston-Mount Dennis Boys and Girls Club is a division of the St. Alban's Boys and Girls club. Their organization is a not-for-profit that runs youth programming in disadvantaged neighbourhoods in the north-west of the City of Toronto. Specifically, it operates in the Jane and Finch, Lawrence Heights, and Weston neighbourhoods. All of these neighbourhoods are considered priority neighbourhoods under the City of Toronto's Strong Neighbourhoods strategy. The Weston-Mount Dennis branch of the club has existed for over a decade, but had not been able to secure permanent 
operating space. Rather, it operated by renting space on an ad hoc basis from other community centres and Toronto District School Board (TDSB) properties. Inspired by Scadding Court Community Centre's temporary infrastructure model, St. Alban's Boys and Girls Club partnered in 2016 with Delta Family Resource Centre, a not-for-profit organization, to explore the possibility of using a temporary urbanist model to create programming space.

\section{Outcomes}

After several years of attempting to secure public land on which to erect temporary structures, the Boys and Girls club secured a lease on parking lot space on a TDSB property, York Humber High School. The club installed a portable office unit on the site with the understanding that it would "look and feel permanent to the community" but be removable by the TDSB if the property desired it to be returned to its previous function. The organization currently has installed only one portable unit, but has plans to install additional modular units to create a 2500 square foot community space (Delta, 2017). Delta has partnered with similar organizations to create similar community spaces throughout Toronto (Reason, 2019).

\section{Role of the Municipality}

The Boys and Girls Club and Delta reaffirmed that City policies were a barrier toward implementation of their project. Specifically, they noted that building standards and inability to find vacant public land were major difficulties (Delta, 2017). They observed that negotiating use of land temporarily with the Toronto District School Board was easier than other City agencies because they have an established process for 
leasing out space to community groups. Nevertheless, the group noted municipal regulations as significant barriers toward the implementation of their project, particularly delays caused by requirement of planning approvals (Delta, 2017).

\section{Community Garden}

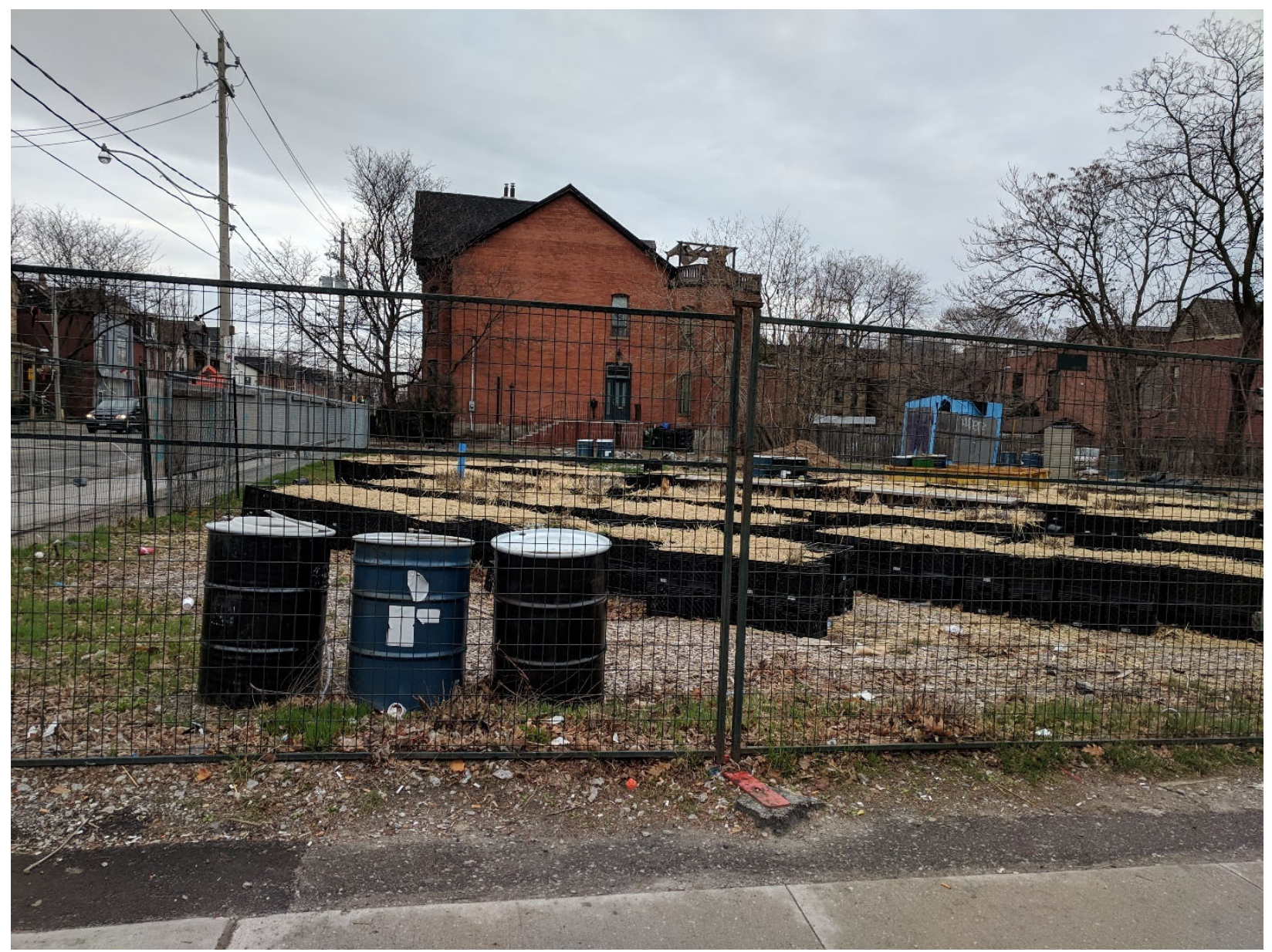

Figure 3: Oben Flats Temporary Community Garden. April 16, 2019.

\section{Description}

Temporary greenspace is another temporary use strategy employed in Toronto to serve equity goals. One key example of this type of development is a community garden located at 307 Sherbourne Street. The property is a vacant lot owned by Oben Flats, 
boutique developers who have proposed a 15-storey rental apartment building on the site. The site has been vacant for almost two decades.

In 2015, as part of the 100in1Day event, urban planner Danny Brown employed tactical urbanist strategies to temporarily repurpose the vacant lot into a community art piece. He purchased coloured pipe cleaners and set them up on a table next to the vacant site asking passersby to create a "garden" by decorating the chain link fence surrounding the property with pipe cleaner flowers. In describing the project, Brown explicitly uses a tactical urbanist discourse to frame the activities. He noted:

While what we were doing was only a temporary solution-the flowers lasted about a month before succumbing to the elements-it felt like the problem we were trying to solve was ultimately less important than the fact that we were trying to solve it. Calling attention to the corner and working together to make it just a little brighter, a little more friendly, gave people who participated a sense of ownership. It might be someone else's property, but that day it was our space. We had reclaimed it, made it useful (Brown, 2015).

This informal, "tactical," temporary activation of the site was only fleeting, however, and was followed by a formalized temporary use of the space initiated by the landowners. Recognizing that the lot would likely remain vacant for some time due to difficulties in obtaining planning approvals for the development, the landowner partnered with Danny Brown, the David Suzuki Foundation, Sustainable TO, and PATCH Projects to solicit proposals for the temporary community use of the site. Ultimately, the lot was repurposed as a community garden operating in milk crates (Skinner, 2015). 


\section{Outcomes}

The community garden is now managed by The Bowery Project that hosts weekly programming and educational workshops on site, donates produce to the NWRC and sells to Evergreen Brickwork's Café Belong and Café Can Can (Bowery Project, 2019). The garden is planted in milk crates sitting on the surface of the lot in order to have minimal impact on the lot's future use and to allow resources to be moved "within a few hours" (Bowery Project, 2019).

Role of Municipality

The role of the municipality in this project was neutral. There are no regulations in place to prohibit the creation of a community garden and, indeed, the City of Toronto does have a program allowing individuals to propose creating temporary urban gardens on public land for which there is some funding available (Friedmann, 2017). In this case, however, temporary utilization of the lot for community purposes was initiated by the developers themselves and was realized through partnering with local and national organizations.

\subsection{Analysis of Common Trends}

These three case studies reveal much about how temporary urbanism is practiced in Toronto. First, we see that temporary use projects operate within a largely formalized planning environment. Unsanctioned projects are not spontaneously created. Rather we see similar top-down processes as in the standard planning framework. Projects are initiated by community groups with some institutional backing, or by developers themselves, and projects typically 
follow processes to get planning approvals. The creation of these sites is complex enough that individuals without institutional support would struggle to realize them.

A second key observation is how central public land is for the creation of temporary community uses. Projects are largely being located on public land in order to operate outside of the typical for-profit rental market in order to achieve sustainable rents.

Finally, a common trend to these projects it that all have identified the City as an absent partner whose policies serve at best a neutral role and at worst significantly hamper projects' viability. In the following section, I examine specific municipal regulations that have an impact on temporary use projects.

It should be noted that all of the studies examined above were ultimately able to secure permits to operate legally in Toronto, despite requiring complex navigation of the bureaucratic system. There is currently no public record of temporary projects that have failed to secure permissions. A recent controversy in Toronto brings to light how formal and informal temporary users may compete over the same public space.

Through the winter of 2019 an informal camp of homeless individuals had been erected on public land beneath the Gardiner expressway. After having given eviction notices, In March, 2019 city crews removed the campsite, citing concerns about safety (Draaisma, 2019). Within three weeks of the camp being cleared, a luxury pop-up dining event was held offering guests the ability to dine in heated 
domes in the park. Significant backlash on social media resulted in anti-poverty activists disrupting the event (The Canadian Press, 2019).

Although an extreme example, this incident highlights that the ability to take advantage of public space in a formalized temporary use framework puts groups without financial or political power at a significant disadvantage. The individuals living beneath the bridge in tents did not have the resources to be able to pursue formalized temporary housing. The luxury event company, however, had both resources and procedural knowledge to be able to get formal permission for its event. That this event was orchestrated on public land and displaced existing informal temporary users, highlights how the system of temporary urbanism in Toronto poses challenges for those lacking knowledge and resources to exploit vacant public spaces.

\section{Section 6: Assessment of CuRrent Regulatory Framework}

At present, Toronto has no specific framework through which to regulate temporary land uses aside from the temporary-use by-law provisions in the Planning Act. Rather than rely on this planning tool in a consistent manner, however, the City approaches temporary uses on a case-by-case basis that sometimes involve the use of

formal planning tools and sometimes do not. Temporary use proponents have observed that this lack of defined process creates significant difficulty for projects initiated without significant support by community organizations or extensive knowledge of planning processes. Organizations note that temporary uses exist in a regulatory grey zone and often challenge traditional planning expectations. Because there are no policies specifically prohibiting the installation of temporary structures but also none explicitly 
permitting them, organizations are dependent on connecting with elected officials or staff to help push projects through.

The practitioners listed in the case studies above have highlighted a number of regulations that actively hinder the use of land on a temporary basis. For the purposes of this study, I will distill here key barriers noted across these case studies:

\subsection{Zoning By-Law 569-2013}

The Toronto Zoning By-Law does not currently distinguish between permanent and temporary approved uses. Rather, temporary projects are expected to meet all of the same standards applied to permanent development. For example, if an organization wished to implement a temporary commercial use on residential properties, it would potentially need to engage in a process of rezoning to accommodate the proposed use and would be required to meet all of the same zoning standards as a permanent structure, including parking requirements, height and density restrictions, and building setbacks. In order to override these existing regulations, temporary uses often require site-specific zoning by-law amendments or variances.

Market 707, for example, has positioned shipping containers at the property line in order to facilitate the connection between businesses and the street (see figure 1). This positioning, however, does not comply with setback requirements in the zoning Bylaw. From a City Planning perspective, variances are required in order to permit this encroachment. Although Section 39 of the Planning Act does provide municipalities with the abilities to create a temporary zoning by-law allowing for the temporary use of the site for alternate land uses, this process can be long and costly for proposed temporary 
uses and places the burden of justifying the need for a new temporary zoning on the applicant. The City of Toronto estimates that a rezoning application can be expected to take a minimum of 9 months (City of Toronto, 2011). As these projects often involve non-traditional uses, however, negotiations with Staff can become quite prolonged. If Staff do not support the rezoning application, appeals to the Local Planning Appeal Tribunal can be very expensive and time consuming. The same process applies for applicants seeking variances from requirements such as parking, which may not be possible or desirable to provide in a temporary context.

\subsection{Disconnection Between Departments and Districts and Overlapping}

\section{Jurisdictions}

A second key issue in Toronto's regulatory framework is the disconnect between between agencies, boards, and City departments in the municipality. In a context in which there is no clear process for approving temporary uses, the same project may be approved in one Community Council area of the city, but not another. As such, there is

a very uneven distribution of approvals experienced across the city. Delta (2017) notes, for example, that:

The experience of community organizations demonstrates that planners in these districts operate separately from each other and that there can be significant differences between how projects are handled across the city. There is also limited coordination or sharing of experience among districts. This means that when it comes to projects that use non-standard building techniques or materials such as shipping containers, it can be difficult to predict how smoothly the approval process will go and how long it will take.

This lack of coordination between departments and the lack of a clear regulatory process leaves temporary projects at a significant disadvantage. They are burdened 
with establishing guidelines for the municipality itself and proving their social benefits on a case-by-case basis.

\subsection{Lack of Tracking of Vacant Spaces}

Finally, there is a notable lack of involvement by the City of Toronto in helping individuals and organizations access public land open for temporary use. It is a characteristic of temporary use in Toronto noted above that projects tend to take advantage of the temporary activation of public space as an alternative to the profitoriented private sector real estate market. Although the City of Toronto, or organizations, such as the Toronto District School Board have approved these projects, it is up to users to identify potential sites themselves.

It has been noted elsewhere that the City of Toronto does not track vacant or underused properties (Fletcher, 2014), and only irregularly announces publicly properties deemed surplus. A lack of centralized database for these properties means that the public is not given equal access to these sites. Rather, those connected into knowledge networks are significantly more able to discover and exploit underutilized public land.

It should be noted, however, that a major improvement toward the goal of utilizing vacant spaces was undertaken by City Council in July, 2018 ,when a previously existing program offering tax rebates for vacant spaces was discontinued. While this is a positive step forward toward encouraging private landlords to make space available for temporary occupation, it only passively supports this outcome and could take a much more active role. 


\subsection{Assessment}

The City of Toronto's lack of a defined process for temporary use in the City is not serving its broader policy goals of promoting equity, democracy, and diversity. The policy grey area surrounding this land use means that the unequal power relationship between regulators, land owners, and the public is made even less equal. Toronto has been called out for being regressive in its policies toward temporary uses. It has been suggested that Toronto is not just behind other cities, it is a decade behind other cities in this realm (Ferguson, 2017). Within the existing model, multiple proponents of temporary use spaces in Toronto have noted that it can be a useful strategy to begin operating sites without approval in order to demonstrate the value of the project to regulators, who then provide retroactive approvals.

The revolutionary appeal of temporary urbanism is its goal of rebalancing power in the land development process away from municipalities and landowners and toward the public. Without a specific policy in place, however, the City of Toronto expects temporary users of space to meet all of the same criteria as a permanent user, and the landlord expects them to provide infrastructure. The user is left with the additional burdens of providing infrastructure to meet regulatory requirements, discovering potential development sites him or herself, and is provided less certainty regarding the investment of their time and resources into land that does not belong to them. As such, the user is potentially at a greater disadvantage than they would have been in a more permanent land development model. At present, an ad hoc policy toward temporary use is not serving the creation of a just city. Insisting that temporary users follow the same permit requirements as permanent developers without offering any incentives or support 
leaves citizens at a heavy disadvantage in the planning process. In the following section, I explore models for how other cities have attempted to overcome the difficulty of equitably regulating temporary uses.

\section{SECTION 7: INTERNATIONAL APPROACHES to Formalizing TEMPORARY URBANISM}

In this section, I highlight different planning cultures regarding the creation and regulation temporary use space. I have chosen three case studies to examine different possible responses a city might take to temporary use and highlight their transferrable lessons for Toronto.

Having examined a number of cities' responses to regulating temporary urbanism, my research has uncovered three key responses that cities have employed to regulate temporary space. Each of these regulatory styles has been implemented to more or less full degrees across a number of other municipalities. These specific case studies have been chosen because they are held up as models in the secondary literature. The three approaches I have isolated are: Managers, Facilitators, and Incentivizers. These three types operate on a scale of involvement from heavy to light in the activation of temporary urban projects.

\subsection{A Managing City: Amsterdam}

Amsterdam, the largest city and capital of the Netherlands, is a major city facing many of the same problems with affordable that are experienced by Toronto. Although Amsterdam's population is much smaller than that of Toronto $(855,047$, with a metro population of $2,431,000)$ its density is higher $(5135$ persons per square kilometer versus Toronto's 4334 persons per square kilometer) (UCL, 2019). Amsterdam was among the earliest promoters of temporary urbanist projects and continues to support major 
temporary development projects such as the construction of the ljburg, Buiksloterham, and NDSM neighbourhoods, the latter of which currently hosts student residences constructed from shipping containers. 250 containers are currently on the site but are scheduled to be removed by 2020 to make room for permanent development (NDSM, 2019).

Amsterdam is unique in its attempt to integrate temporary use planning into its formal planning framework, striving to balance the desire to allow for creativity and spontaneity associated with "weak planning" versus "master planned" developments, and the certainty and quality associated with a strong regulatory framework (Savini, Salet, \& Markus, 2015). Amsterdam has sought to achieve this balance by designating new neighbourhoods specifically for temporary use. The municipality has set guidelines for land uses typical of a masterplan with the understanding that any development that occurs within the established framework must be designed to be removed at a later date. In this way, the municipality hopes to harness the power of experimental, iterative development in order explore possibilities for new communities (Savini, Salet \& Markus, 2015).

Within this framework, some land has been designated for specific purposes as would be typical in traditional land use models. For example, some land is designated for residential or office uses. These lands are designed to be occupied for longer time frames. Other properties in the new neighbourhood have been left open for experimentation with no specific designation. These areas are designed to be occupied for a shorter time frame and make space for highly experimental small-scale projects such as art installations (Krawchenko, 2018). 
Properties in this temporary district are required to meet zoning specifications, but the municipality has created area-specific zoning requirements that are aligned with the limitations of moveable infrastructure (Savini, Salet, \& Markus, 2015).

In addition to its program of planned temporariness, Amsterdam has also sought to encourage temporary land development by two additional means: by creating a simplified approvals process for temporary projects that are considered to have public good, and by actively identifying vacant lands that might function as sites for temporary use (Broeks, 2016).

Amsterdam's simplified approvals process derives from The Crisis and Recovery Act, implemented by the national government in 2010 and updated in 2014, which allows municipalities to quickly approve projects deemed beneficial. Dutch regulators have noted that this process has meant that regulatory barriers for temporary use projects are now relatively minimal (Savini, Salet, and Markus, 2015).

A third key initiative was the creation of a centralized database of vacant lands open for temporary use within municipal boundaries. The municipality published an interactive online map listing municipal properties available for temporary exploitation and also crowdsourced information from the community to create the map (Broeks, 2016).

Amsterdam is unique in its active promotion of temporary uses in the municipality and the central role of the municipal government in creating them. The outcome of these projects has been that a number of highly creative initiatives have been able to occur which have functioned to fill service gaps and allow for highly democratic 
participation in the planning process. Amsterdam has sought to balance a need for flexibility with the assurance of quality and stability. It has done so through active involvement in, but not direct control over temporary use projects.

\subsection{A Facilitating City: London}

Like Amsterdam, the City of London in the United Kingdom faces many of the same development pressures and affordability issues as Toronto. Its urban population is nearly ten million with a metro population of over fourteen million people. It is also a densely-populated city at 5,590 persons per square kilometer (London Datastore, 2019).

Beginning in 2008 as a result of the subprime mortgage crisis and ensuing delay in development, the City of London has adopted a more or less supportive attitude toward temporary development. London's new Official Plan, currently under review, introduces specific policies for temporary use, dubbed "meanwhile uses." Policy H4 notes that boroughs "are encouraged to identify opportunities for the meanwhile use of sites for housing to make efficient use of land while it is awaiting longer-term development" (City of London, 2019).

As in Toronto, temporary uses, dubbed "meanwhile uses," in London typically have been created as a response to lack of available land. A recent study concluded "Not only does London lack space to take risks and set up shop on the cheap, it also means that non-market uses such as social housing, community and artistic spaces cannot afford space in the city without hefty subsidies (Bosetti \& Colthorpe, 2018, 8). 
Within this context regulators frame temporary uses as a tool to achieve "inclusive growth" (Bosetti \& Colthorpe, 2018).

London currently has at least 51 sites that are being used for temporary use totalling 188,600 square metres. Many of the projects were achieved not through direct action by the municipal government, but rather through partnerships with publiclyfunded community organizations Bosetti \& Colthorpe, 2018). In London, the major organization responsible for the promotion of temporary uses is Meanwhile Space, a community interest company funded by the Department for Communities and Local Government, a department within the national Ministry of Housing, Communities, and Local Government. Meanwhile Spaces helps to co-ordinate projects between local governments, landowners, and users (Meanwhile Spaces, 2019).

As part of this facilitation role, some London boroughs have created standard leases for temporary uses, attempting to normalize and simplify temporary uses of vacant sites and to protect both user and owner's interests (Meanwhile Spaces, 2019). In addition, like Amsterdam, London tracks properties that are left vacant for over 2 years, meaning that there is a public database of potential temporary use spaces available (Bosetti \& Colthorpe, 2018).

Although London continues to face some of the same barriers toward implementation of temporary spaces, including a relatively inflexible regulatory framework, it has sought to overcome these barriers by taking on a role as facilitator rather than manager of temporary use projects. 


\subsection{An Incentivizing City: Vancouver}

Finally, the City of Vancouver, Canada is among the world's least affordable urban areas. Demographia's International Housing Survey of 2019 rated Vancouver as the second least affordable housing market in the world second only to Hong Kong (Demographia, 2019). In response to this severe lack of affordability, Vancouver has introduced policies encouraging the occupation and utilization of land within the municipality. These policies take two forms, those that penalize vacant spaces, and those that incentivize temporary uses.

Vancouver's vacant space policies are very new, and so their impact is not yet clear. They have, moreover, been thus far limited to residential properties. In 2018 , Vancouver instituted an "empty homes tax" which is intended to motivate owners of vacant homes to open them up to the rental market with the goal of reducing residential rental costs in Vancouver. Properties left vacant are subject to a $1 \%$ tax of the assessed value of the home (City of Vancouver, 2019). Early results have indicated that residential property owners have perceived the vacancy tax as a significant enough burden to begin to rent out their homes (The Canadian Press, 2019).

In addition to municipal policies penalizing vacancy, the province of British Columbia also has longstanding policies that encourage temporary use of vacant land for community purposes. The provincial tax assessment structure encourages owners of vacant lots to repurpose those lots temporary as community gardens by allowing the temporary shift in land use to be reflected in the assessment classification. By creating a "recreational or non-profit use" on the site, the land can be reclassified to "recreational 
or non-profit" land, which makes owners eligible for an up to $70 \%$ reduction in taxes owed (Stueck, 2018).

Although there has been criticism of this system of tax breaks for the repurposing of vacant land in terms of the City of Vancouver losing out on significant amounts of revenue, the system is highly effective in creating community greenspace in areas where land values would prohibit the creation of significant publicly-owned greenspaces. As much as $7 \%$ of all of the city's community garden space was created as a result of temporary conversions in 2012 (O'Connor, 2013).

Although Vancouver's incentive programs for temporary use are limited in scope to creating community space and avoiding empty residential properties they serve as a model that could be adopted to other land uses and hint at the success offering financial incentives might have at opening up privately-owned vacant land for temporary use projects. This same model could, for example, be extended from community gardens to any temporary land use designed to benefit the community and vacant property taxes could be applied more generally to other land uses beyond residential to encourage their short-term activation.

These case studies reveal that municipalities have taken a variety of approaches to regulating and encouraging temporary uses of space that have positive impacts for their communities. Amsterdam collaborates with citizens to balance spontaneity and certainty in the planning process, London facilitates temporary uses in an effort to use land efficiently, while Vancouver uses a carrot and stick approach to encourage beneficial interim land uses and avoid the hoarding of empty properties. In the following section I highlight how these lessons might be translated to the context of Toronto. 


\section{Section 8: Proposed Policy Framework for Toronto}

The goal of these proposed policy changes is to better align temporary use in the City of Toronto with the benefits of equality, diversity, and democracy that are currently ascribed to it. It does this by attempting to rebalance power away from the municipality and toward creators of temporary spaces. It highlights how lessons from elsewhere can help address criticisms of its current policy framework. At the core of these recommendations is the idea that the City of Toronto must take a much more active role in encouraging and mediating temporary uses in order to achieve its own goals for sustainable development. By taking an active role in the regulation and facilitation of temporary uses in Toronto and simplifying the permits process it removes much of the work of navigating bureaucracy away from creators of temporary spaces and places it on the city, meaning that those with fewer resources or knowledge of the planning process will have greater ability to tap into the opportunities afforded by vacant lands and within a much shorter timeframe.

The recommendations listed below are inspired by international case studies, but respond to the barriers identified in the policy review above. By removing barriers to participation posed by a complex and inconsistent system and one that requires users to identify potential sites themselves, this system attempts to provide equal access to those with and without the resources to navigate the bureaucratic system. As identified by CAWI, identifying and removing barriers to participation is key to increasing equity and inclusion (CAWI, 2015). 


\subsection{A Clear Process}

One of the key lessons that can be taken from the international case studies is that they identify temporary land use as a distinct form of development and create clear processes for its creation. In Amsterdam, this process was highly orchestrated by the municipal government. In London, the process was merely outlined briefly and achieved through the mediation of an arms-length government agency, who assisted potential temporary developers.

In order to improve the justness of its processes, Toronto should also create a clear definition of and framework for processing temporary uses. This framework must be clear in its application among all agencies and divisions within the municipal government so that there is consistency across all areas of the city. An amendment to the zoning by-law could be a useful tool for legitimizing and regularizing temporary use practices. Instead of applying for a zoning by-law amendment, certain uses identified as benefiting the community could be permitted as-of-right for limited time periods. This change would significantly reduce regulatory barriers faced by temporary use projects.

The municipality could restrict this zoning to certain areas where temporary activation of land could be most beneficial, for instance, the way Residential Apartment Commercial zoning has been applied, allowing for additional land uses in apartment communities as a tool for urban regeneration. ${ }^{1}$ Alternatively, the Official Plan could

\footnotetext{
${ }^{1}$ Residential Apartment Commercial Zoning allows for small-scale, non-residential land uses such as markets, shops, small businesses, and classes in Toronto's high rise apartment communities where they were previously prohibited under the zoning by-law.
} 
merely highlight temporary use as a priority, as London has proposed, instructing all departments and agencies to encourage temporary uses when possible. This model would solve a key problem encountered by practitioners in Toronto, the lack of clarity and consistency in the municipality's treatment of temporary use applications.

\subsection{A Database of Properties}

Secondly, following the model of London and Amsterdam, the City of Toronto should create a mapping system to make a public database of vacant or underused sites deemed suitable for temporary use by the community. This model has already begun to be adopted by the City of Montréal in Canada. The value of creating such a list removes a significant burden from the public in terms of identifying appropriate spaces for development, and also would give much more equal access to underused public lands. At present, community groups with inside knowledge or access, such as Kevin Lee at Scadding Court Community Centre, are able to take advantage of public land through informal processes. A public database would make identifying opportunities for temporary use much more democratic.

\subsection{Tax Incentives}

In addition to regulating and promoting public spaces more effectively, the City of Toronto could also play a role in encouraging empty development sites to be used for public good. At present there are no incentives for landowners to lease their properties for temporary use projects. Indeed, many landowners interviewed in other cities have suggested that they are reluctant to allow for temporary uses because of concerns about insurance and about being able to remove popular local initiatives after they have 
become established. Although this data does not exist for Toronto's landowners, it is likely that they may have similar concerns.

The City of Toronto could play an active role in promoting this use by employing a system of tax incentives and disincentives as has been explored in Vancouver. Property owners repurposing land for community uses, such as gardens, markets, or service spaces would be more likely to permit temporary uses on site if they received a reduction in taxes payed. This incentive would help to open up much needed space for temporary development. Likewise, the City could go much farther than its current policy of abolishing special tax rebates for vacant property. A punitive vacancy tax would encourage property owners to allow spaces to be used on a temporary basis.

\subsection{Centralized Application System}

Finally, the City of Toronto could simplify and coordinate temporary use applications through founding an Office for Temporary Use. Much like Meanwhile Space in London, this office would serve as a point of contact with the City, coordinate between agencies and departments. This office would greatly reduce the burden on applicants attempting to navigate complex land use systems in order to make temporary projects viable. It would also remove much of the burden for coordinating these projects from community organizations and redirect it toward the municipality. This would help to redistribute power away from the municipality and toward the community.

\subsection{Role of City Divisions}

This framework has largely focused on addressing planning barriers toward an inclusive framework for temporary use, highlighting barriers for identification and 
utilization of vacant lands posed by the current system. In addition to the role that the City of Toronto's Planning department might fill, it should be recognized that there is also potential to engage with departments relating to economic and neighbourhood service departments to encourage this type of land use.

The City of Toronto's Economic Development and Culture Department offers program support for small business initiatives that could be co-ordinated with temporary urbanism initiatives. Likewise Employment and Social Services could be approached to identify and fund opportunities for communities to create and access services in temporary projects. These initiatives could work in coordination with a regularized and formalized planning system to help facilitate temporary use projects for disadvantaged members of the community.

\section{CONCLUSION}

This proposed framework seeks to address many of the concerns voiced by creators of temporary spaces in Toronto by connecting them with solutions tested in the international context. At its core, this framework is focused on attempting to capture the goals of equity, democracy, and diversity that are associated with the temporary use framework by working to redistribute power. In the existing case-by-case system the ability to navigate municipal bureaucracy requires significant knowledge and financial resources and can cause delays of months to years to institute a project that may only last months. Vulnerable individuals, such as recent immigrants, people living in poverty, and those with disabilities are less able to compete for access to these temporary spaces or even become aware of their possibility to be developed as temporary spaces. By simplifying the application process and engaging in identifying and making publicly 
available spaces appropriate for temporary development, the City would then take on some of the regulatory burden associated with developing these sites, thereby making the process more accessible. Giving a greater variety of people the potential to take advantage of these processes makes for a more inclusive, diverse, and equitable city.

This plan also recognizes, however, that regulations exist for a reason. Some temporary uses pose public health and safety concerns, such as the example of the camp of homeless individuals underneath the Gardiner Expressway (Draaisma, 2019). As such, this proposal also seeks to balance profitability, access, and protection of safe and quality construction with the creativity and radical democracy of temporary uses. With the formalization of temporary uses, there is a risk of municipalities and landowners maintaining all of the rights and privileges of the traditional land use system while placing additional burdens of precarity and uncertainty on land users. A more balanced and flexible regulatory system is one tool that can be used to help address these imbalances and encourage true bottom-up city building. 


\section{$\underline{\text { Works Cited }}$}

Andres, L. (2013). Differential spaces, power hierarchy and collaborative planning: A critique of the role of temporary uses in shaping and making places. Urban Studies, 50(4), 759-775.

Bishop, P., \& Williams, L. (2014). The temporary city. Routledge.

Bosetti, N. (2018). Meanwhile Use in London. Retrieved from https://www.centreforlondon.org/project/meanwhile-use-london/

Brenner, N. (2014, March 24). Is "Tactical Urbanism" an Alternative to Neo-Liberal Urbanism? Museum of Modern Art. Retrieved from https://post.at.moma.org/content items/587-is-tactical-urbanism-an-alternative-toneoliberal-urbanism

Broeks, T. (2016, July 26). From Amsterdam to Refill. Retrieved from https://refillthecity.wordpress.com/2016/07/26/from-amsterdam-to-refill//

Brown, D. (2015, July 27). An 100in1Day Story. Open Cities. Retrieved from http://opencityprojects.com/an-100in1day-story/.

Carlberg, A. (2017, Oct 26). Google Just Opened A Free Donut Shop in Toronto. Retrieved from https://www.blogto.com/tech/2017/10/google-home-mini-donuttoronto/

CAWI. (2015). Advancing Equity and Inclusion: A Guide for Municipalities. Retrieved from http://www.cawi-ivtf.org/sites/default/files/publications/advancing-equityinclusion-web.pdf

Chief Planner. (2007, March 5). Staff Report: Proposed Parking Standards for Selected Commercial and Residential Uses: Consultation and Next Steps. City of Toronto. Retrieved from https://www.toronto.ca/legdocs $/ \mathrm{mmis} / 2007 / \mathrm{pg} / \mathrm{bgrd} / \mathrm{backgroundfile-}$ 2399.pdf

City of London. 2019. Draft New London Plan. Retrieved from https://www.london.gov.uk/what-we-do/planning/london-plan/new-londonplan/draft-new-london-plan/chapter-4-housing/policy-h4-meanwhile-use

City of Toronto. (2002); Consolidated 2015. Toronto Official Plan, Office Consolidation, June 2015.

City of Toronto. (2011). Toronto Development Guide. Retrieved from https://www.toronto.ca/wp-content/uploads/2017/08/9783-guide sectionA.pdf

City of Toronto. (2017). Toronto Strong Neighbourhoods Strategy 2020. Retrieved from https://www.toronto.ca/wp-content/uploads/2017/11/9112-TSNS2020actionplanaccess-FINAL-s.pdf 
Colomb, C. (2012). Pushing the urban frontier: temporary uses of space, city marketing, and the creative city discourse in 2000s Berlin. Journal of urban affairs, 34(2), 131152.

Conseil Jeunesse de Montreal. (2019). Avis sur l'utilisation des espaces vacants a Montreal: une perspective jeunesse. Retrieved from https://issuu.com/entremise/docs/26 0717 entremise espaces vacants

Delta. (2017). Pop-Up Infrastructure: Reinventing Community Space Feasibility Study. Retrieved from https://popupinfrastructure.com/

Deveau, D. (2018, March 5). Popup Shops a Low-Risk Starting Point for Testing Market Waters. Financial Post. Retrieved from https://business.financialpost.com/entrepreneur/growth-strategies/popup-shops-alow-risk-starting-point-for-testing-market-waters

Draaisma, M. (2019, March 13). City Crews Demolish Homeless Encampment under Gardiner Expressway. CBC News. Retrieved from https://www.cbc.ca/news/canada/toronto/city-crews-clear-encampment-undergardiner-expressway-homeless-1.5054918.

Fainstein, S. S. (2010). The just city. Cornell University Press.

Fainstein, S. S. (2014). The just city. International Journal of Urban Sciences, 18(1), 118.

Ferguson, L. (2017, August 17). Repurposed Shipping Containers are the Latest Affordable Space Trend, but City Planning Policies Need to Catch up. Now Toronto. Retrieved from https://nowtoronto.com/news/repurposed-shippingcontainers-affordable-space-trend/

Ferreri, M. (2015). The seductions of temporary urbanism. ephemera, 15(1), 181.

Ferreri, M., \& Lang, A. (2016). Notes From the Temporary City: Hackney Wick and Fish Island 2014-2015. public works.

Finn, D. (2014). DIY urbanism: implications for cities. Journal of Urbanism: International research on placemaking and urban sustainability, 7(4), 381-398.

Friedmann, C. (2017 November 3). How to Feed a Hungry City. The Globe and Mail. Retrieved from https://www.theglobeandmail.com/news/toronto/new-urbanagriculture-projects-in-toronto-are-struggling-to-take-root-as-publicawarenesslags/article36835601/

Graham, S. (2012). Temporary Uses as Tools for Urban Development. Retrieved from https://mspace.lib.umanitoba.ca/bitstream/handle/1993/5048/Graham Shelagh.pdf ?sequence $=1$

Hume, C. (2014, May 30). Temporary Toronto's Lasting Results: Hume. Toronto Star. Retrieved from https://www.thestar.com/news/gta/2014/05/30/temporary torontos lasting results hume.html. 
Königs, M. (2012, May 3). It's not Just a Solution, it's a Way of Life. The ProtoCity. Retrieved from http://theprotocity.com/its-not-just-a-solution-its-a-way-of-life/.

Krawchenko, T. (2018, March 12). Social Trust: An Invisible Glue for Better Urban Planning. Retrieved from http://oecdinsights.org/2018/03/12/social-trust-aninvisible-glue-for-better-urban-planning/.

Leblanc, D. (2018, May 11). A Market Made of Containers Fills a Neighbourhood Gap. The Globe and Mail. Retrieved from https://www.theglobeandmail.com/life/homeand-garden/architecture/a-market-made-of-containers-fills-a-neighbourhoodgap/article14901749/

Lee-Shanok, P. (2018, November 12). A Year Into King Street Pilot Project, it's not Clear if Metrics or Politics will Decide its Fate. CBC News. Retrieved from https://www.cbc.ca/news/canada/toronto/king-street-pilot-marks-one-yearanniversary-1.4900969

Lehtovuori, P., \& Ruoppila, S. (2017). Temporary Uses Producing Difference in Contemporary Urbanism. Transience and Permanence in Urban Development, 4763.

London Datastore. (2019). Land Area and Population Density, Ward and Borough. Retrieved from https://data.london.gov.uk/dataset/land-area-and-populationdensity-ward-and-borough

Lydon, M., \& Garcia, A. (2015). A tactical urbanism how-to. In Tactical urbanism (pp. 171-208). Island Press, Washington, DC.

Maciver, M. (2010, August 8). Eric Reynolds, Master of Low-Cost High-Return Public Space Interventions in London and NYC. Retrieved from https://www.pps.org/article/eric-reynolds-master-of-low-cost-high-return-publicspace-interventions-in-london-and-nyc.

Madanipour, A. (2018). Temporary use of space: Urban processes between flexibility, opportunity and precarity. Urban Studies, 55(5), 1093-1110.

McGrath, J.M. (2017, February 13). A Waste of (Urban) Space. TVOntario. Retrieved from https://www.tvo.org/article/a-waste-of-urban-space.

McKeen, A. (2017, December 19). Shipping Container Marketplace Stackt Thinks Inside the Box. Toronto Star. Retrieved from

https://www.thestar.com/business/2017/12/19/shipping-container-marketplacestackt-thinks-inside-the-box.html.

McLaughlin, A. (2017, July 28). City Replaced This Man's Homemade Tom Riley Park Staircase for \$10k After Controversy. CBC News. Retrieved from https://www.cbc.ca/news/canada/toronto/tom-riley-park-stairs-rebuilt-1.4227365

Nelischer, C. (2013, September 14). 10 No Brainers: Provide Permits for Pop-Ups. Spacing Toronto. Retrieved from http://spacing.ca/toronto/2014/09/19/10-brainersprovide-permits-pop-ups/. 
Németh, J., \& Langhorst, J. (2014). Rethinking urban transformation: Temporary uses for vacant land. Cities, 40, 143-150.

Ontario Human Rights Commission. (2019). Preventing, Reviewing, and Removing Barriers. Retrieved from http://www.ohrc.on.ca/en/policy-primer-guide-developinghuman-rights-policies-and-procedures/4-preventing-reviewing-and-removingbarriers

Oswald, P., Overmeyer, K. Misselwitz, P. (2012). Urban Catalyst: The Power of Temporary Use. DOM Publishers.

Patterson, C. (2017, July 19). Experts Predict 2018 to be 'Year of the Pop-Up' [Feature]. Retail Insider. Retrieved from https://www.retail-insider.com/retailinsider/2017/7/pop-up

Patti, D., \& Polyak, L. (2015). From practice to policy: frameworks for temporary use. Urban Research \& Practice, 8(1), 122-134.

Pfeifer, L. (2013). The Planner's Guide to Tactical Urbanism. Montreal, Canada Page.

Powell, N. (2018, November 23). Record Low Downtown Vacancy Rates Pushing Businesses to Move to the Suburbs-but They're not Complaining. Financial Post. Retrieved from https://business.financialpost.com/real-estate/propertypost/suburban-offices-outpace-downtown-for-the-first-time-in-a-year.

Reason, C. (2019). Pop-Up Family and Parenting Centre Underway in Etobicoke. Retrieved from https://www.toronto.com/news-story/9029442-pop-up-family-andparenting-centre-underway-in-etobicokel

Ricci, T. (2019, April 10). Downtown Market Made of 120 Shipping Containers is now Open for Business. CBC News. Retrieved from https://www.cbc.ca/news/canada/toronto/stackt-marketplace-shipping-containers1.5092795.

Rider Levett Bucknall. (2019). RLB Crane Index North America - January 2019. https://s28259.pcdn.co/wp-content/uploads/2019/01/2019-January-CraneIndex.pdf

Skinner, J. (2015). Community Invited to have Input for Vacant Lot at Sherbourne and Gerrard Until Development Application Approved. Retrieved from https://www.toronto.com/news-story/5937399-community-invited-to-have-input-forvacant-lot-at-sherbourne-and-gerrard-until-development-application-approved/

Sloan, W. (2018, July 3). Students Give a new Shape to King Street. Retrieved from https://www.ryerson.ca/news-events/news/2018/07/students-give-a-new-shape-toking-street/

Sweeting, A. (2015). The Value of Temporary Urbanism in Creating Responsive Environments. Retrieved from https://www.brookes.ac.uk/uploadedfiles/faculty of technology, design and envir 
onment/school of the built environment/pagebuilder pages/be/courses/urban d esign portfolio/temporary\%20urbanism.pdf

Stueck, W. (2018, May 1). Community Gardens' Zoning Designation can Mean Significantly Lower Assessments. The Globe and Mail. Retrieved from https://www.theglobeandmail.com/news/british-columbia/community-gardenszoning-designation-can-mean-significantly-lower-assessments/article14175240/.

The Canadian Press. (2019, February 6). City of Vancouver Says 2018 Empty Homes Tax Eased Tight Rental Market. Retrieved from https://www.cbc.ca/news/canada/british-columbia/city-of-vancouver-says-2018empty-home-tax-cut-number-of-homes-sitting-vacant-1.5008365

The Canadian Press. (2019, April 3). Poverty Activists Target Luxury Outdoor Dinner in Toronto Staged Near Former Homeless Camp. The Globe and Mail. Retrieved from https://www.theglobeandmail.com/life/article-poverty-activists-target-luxuryoutdoor-dinner-in-toronto-staged-near/

TREB. (2018). Commercial Realty Watch Third Quarter 2018. Retrieved from http://www.trebcommercial.com/public/comwatch/com back/2018/pdf/cw18Q3.pdf

Vooren, R., Vleugel, C., Zwietering, T. (2016). Platform for Temporary Use on the Northern Banks of the IJ. Colophon. Retrieved from http://stealth.ultd.net/wpcontent/uploads/2016/07/platform.pdf

White, M. M. (2011). Sisters of the soil: Urban gardening as resistance in Detroit. Race/ethnicity: Multidisciplinary global contexts, 5(1), 13-28.

Yiftachel, O. (1998). Planning and social control: Exploring the dark side. Journal of planning literature, 12(4), 395-406. 